\title{
Modelling the dynamics of urban transport: a simplistic approach to traffic impact assessment
}

\author{
I. M. Röntgen \\ North West University (Potchefstroom Campus), South Africa
}

\begin{abstract}
Development pressure and the need for urban integration in South African towns, caused by spatial segregation due to the impact of policies of the previous political dispensation, gives rise to various ad hoc land development applications in the form of rezoning and township establishment. Land use and transportation planning is integrated and the impact of traffic due to such changes is key in the approval of land development applications. The transition to a democratic society also led to a lack of capacity and practitioners with skills to conduct traffic impact assessments within municipalities.

This paper deals with the application of a simplistic procedure to undertake traffic impact assessments (TIAs) in small and intermediate towns where there are restricted levels of data and information available. The research is based on a case study undertaken within the area of influence of the North West University (Potchefstroom Campus) and includes the assessment of traffic impact based on two Town Planning Amendment Scheme applications in the study area.

The paper covers existing planning knowledge; analysis of the inter-traffic movements; intra-traffic movements and quantification of the traffic impact based on the proposed land use amendment applications. The paper is concluded by the quantification of the traffic impacts supported by recommendations in order to mitigate the traffic impact within the study area where the demand for spatial transformation is high. The assessment will be based on land use and transport integration principles and impact quantification.
\end{abstract}

Keywords: land use, traffic impact assessment, transportation planning, transport modelling, simulation. 


\section{Introduction}

From Stover and Koepke [1], traffic impact assessments (TIAs) provide guidance on the effect that development will have on the operation of the local road network. Furthermore, the TIA makes recommendations on the extent of road infrastructure upgrading required to ensure that traffic congestion levels are kept within acceptable limits. If infrastructure upgrading is not possible, the TIA makes recommendations on development limitations that should be imposed on land development applications.

The Institute of Transportation Engineers recommends a checklist of requirements for the TIA [2]. These guidelines also form the basis for the Cape Cod Commission Guidelines for TIA [3]. The South African guidelines were developed in 1997 [4]. The minimum contents of a TIA are quite comprehensive and may be impractical for certain situations (small to intermediate towns) and sometimes for the limited budget of a developer. Therefore the content of a TIA for small towns should focus on six items that are deemed important due to the circumstances described above:

- description of the impact area;

- $\quad$ characterization of the baseline traffic;

- $\quad$ assessment of infrastructure;

- $\quad$ ingress and egress from the proposed sites;

- $\quad$ parking provision and loading and off loading;

- traffic impact mitigation.

The phenomenon of transport and land use represents an integrated engagement that is reflected in ad hoc development and planning documents applicable to the sites included in the amendment schemes. The traffic impact assessment statement (TIAS) could thus not be adjudicated without relating it to the existing knowledge. The content of the documents included in [5-11] informs the traffic impact assessment statement.

\section{Existing knowledge}

The data and information base as contained in the existing knowledge should be used in the formulation of the TIAS. In order to understand the underlain relationships between transport and land use management the input of the following existing knowledge within the study area is used:

- $\quad$ Tlokwe City Council SDF (Spatial Development Framework) Figure 1 shows the SDF for the Tlokwe City Council (TCC) [10].

- Tlokwe City Council ITP (Integrated Transport Plan)

Figure 2 shows the (alternative) road classes as included in the Draft ITP [10]. For the purpose of the paper the road classification included in the ITP will be used for assessment of the various sites. 


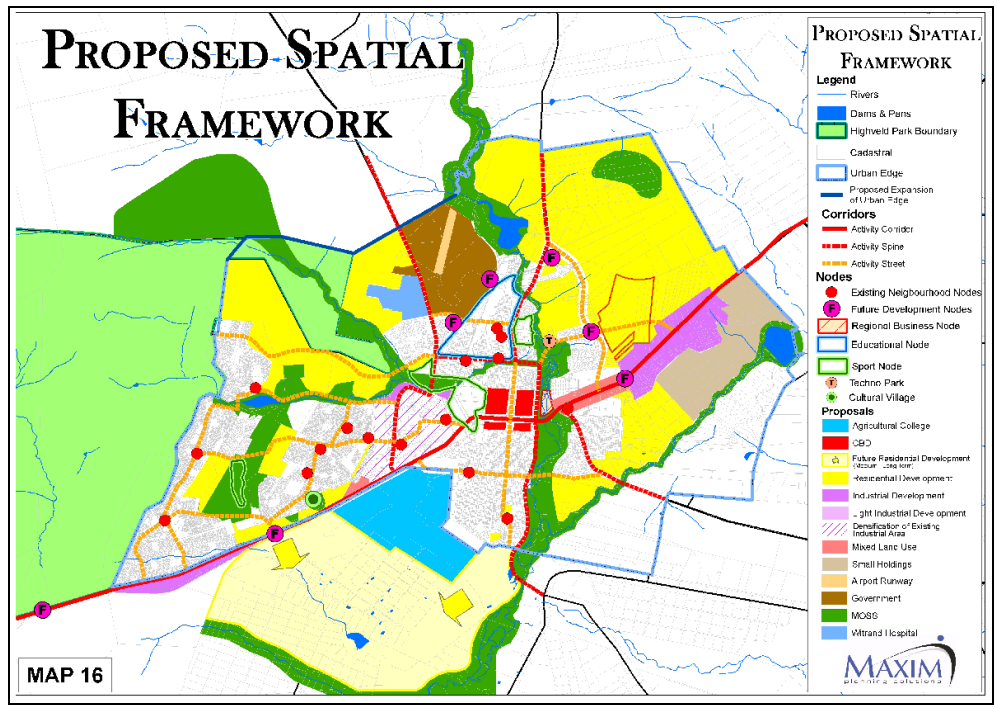

Figure 1: $\quad$ TCC draft SDF. Source: Tlokwe City Council [9].

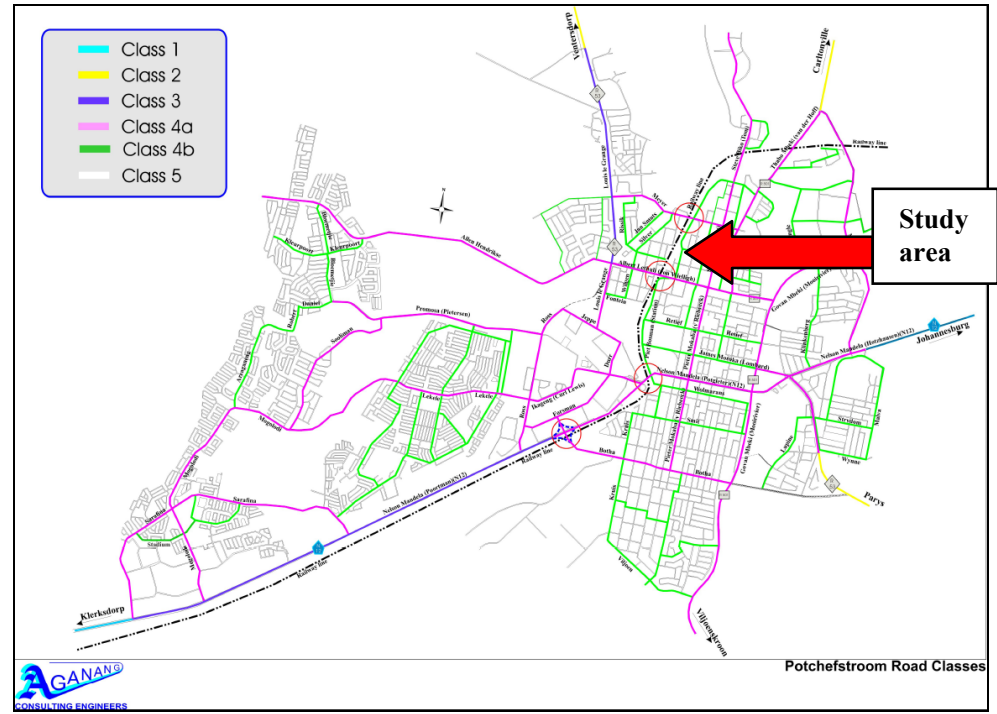

Figure 2: $\quad$ Road classes TCC. Source: Tlokwe City Council [9].

\section{Case studies and location}

This paper examines two case studies in the study area for which TIAs were prepared:

- Case 1: Amendment scheme 1438.

- Case 2: Amendment scheme 1442. 


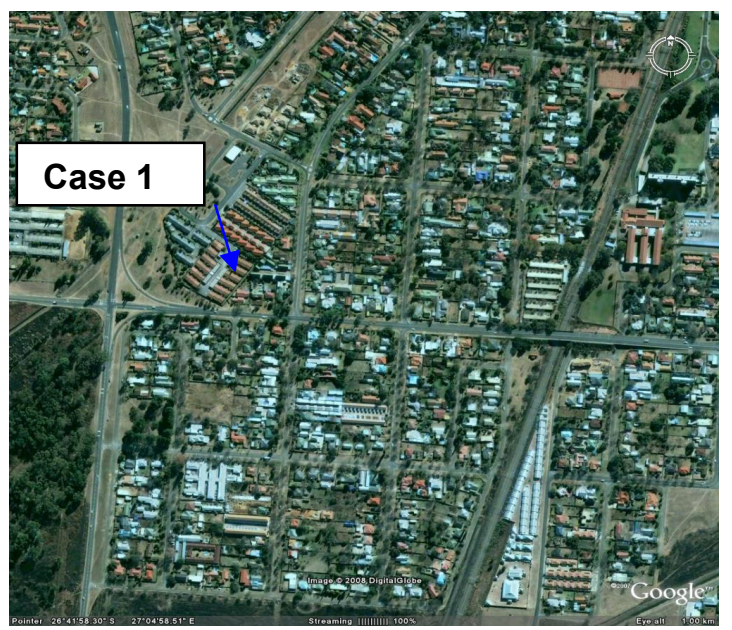

Figure 3: $\quad$ Location of the site involved in Case 1.

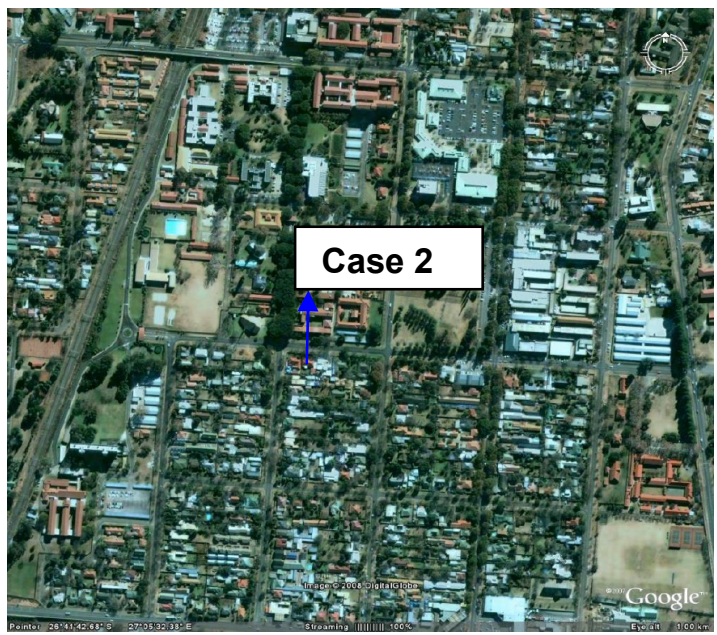

Figure 4: $\quad$ Location of the site involved in Case 2.

The location of the sites involved in the scheme applications area are shown in Figures 2 and 3. The sites are located within an area classified as a densification area.

\section{Inter traffic (town orientated) and movement patterns}

As can be deduced from Figure 2 the inter traffic and transport movement within the spatial system of TCC is being served through Class 1, Class 2 and Class 3 roads. The Class 1, 2 and 3 roads functions as Class 4 roads and is therefore presented as such in Figure 2. 
The road classification in terms of the TCC ITP (2008) [10] which serve Case 1 and Case 2 are as follows:

- Class 4: Local Distributor Roads.

- Class 4a: Collector Roads fulfilling the purpose of linking suburbs or different areas with class 3 routes.

- Class 4b: Collector Roads fulfilling the purpose of linking suburbs or different areas with class 3 routes.

- Class 5: Access Roads, within suburbs linking traffic to class 4 routes.

The proposed development sites are being served by a Class $4 \mathrm{a}$ road (collector linked to minor arterials) Von Wielligh (east west spine) and the Louis le Grange (north south spine) (R53) on the western side of the study area. To the eastern side the proposed development will also be served by a Class $4 \mathrm{a}$ road. Both sites included in the amendment schemes are located on Class $4 \mathrm{~b}$ roads (collector linking suburbs) in terms of the classification in Figure 2. This makes all of the properties accessible from a inter traffic perspective.

Table 1: $\quad$ Study area: parking and transport stock per erf.

\begin{tabular}{|r|r|r|r|r|r|r|r|r|}
\hline & \multicolumn{2}{|c|}{ Parking } & \multicolumn{5}{c|}{ Motor vehicles per erf \% } & \multicolumn{2}{c|}{$\begin{array}{c}\text { Garage } \\
\text { facilities }\end{array}$} \\
\cline { 2 - 9 } Ward & No. & $\%$ & Cars & Motorcycle & Bicycle & Other & No. & $\%$ \\
\hline $\mathbf{2}$ & 593 & 33 & 1133 & 86 & 589 & 16 & 911 & $38.50 \%$ \\
& & & $23.90 \%$ & $40.40 \%$ & $-33.80 \%$ & - & & \\
\hline $\mathbf{4}$ & 404 & 22.5 & 623 & 23 & 158 & 13 & 503 & $21.30 \%$ \\
& & & $18.10 \%$ & $10.80 \%$ & $-9.10 \%$ & - & \\
\hline $\mathbf{6}$ & 204 & 11.4 & 434 & 23 & 255 & 2 & 252 & $10.70 \%$ \\
& & & $12.60 \%$ & $10.80 \%$ & $-14.60 \%$ & $-5.40 \%$ & & \\
\hline 7 & 594 & 33.1 & 1252 & 81 & 740 & 6 & 700 & $29.60 \%$ \\
& & & $36.40 \%$ & $38.00 \%$ & $-42.50 \%$ & - & \\
\hline
\end{tabular}

Source: Table 2.14 [7].

It should however be noted that the study area is being served by a predominantly grid lay-out resulting in numerous intersections. The road system is being managed by four way stop streets and robots on some of the higher capacity roads. This physical feature of the road network prohibits inter as well as intra traffic movement.

If the road classes as identified in terms of the TCC ITP (2008) [10] is assessed from geometrical and structural engineering design standards, the conclusion is that if such roads fulfil the functions as allocated, future upgrading 
of these roads generally will be required as to cater for design speed; capacity and optimal utilization in terms of mode distribution.

At present traffic safety in the study area is being promoted through implementation of ad hoc traffic calming measures. From a capacity viewpoint Von Wielligh Street is showing capacity problems from Tom Street to Mooiriver Avenue. Traffic surveys conducted in 2008 clearly indicated that the road capacity needs to be increased by two additional traffic lanes from west to east and east to west.

The surveys also indicated that there is a need for dedicated cycle and pedestrian lanes between the study area and the CBD. The sharing of road surfaces between motorized vehicles and pedestrians is a traffic hazard and threat. Furthermore, the surveys undertaken have shown the following parking and transport supply and demand per erf within the study area apply (Table 1):

\section{Evaluation of the two case studies (sites)}

\subsection{Details of rezoning}

Case 1: Amendment Scheme 1438 provides for the amendment of the Potchefstroom Town Planning Scheme of 1980 from Residential 1 to Residential 4 for dwelling units with or without outbuildings and related residential uses (Refer to Table 2).

Table 2: $\quad$ Land use rights applied for Case 1 and Case 2.

\begin{tabular}{|c|c|c|}
\hline & Case 1 & Case 2 \\
\hline FAR of & 2 & 1.95 \\
\hline Max. height & $\begin{array}{l}3 \quad \text { storey's (parking }+2 \\
\text { storey's) }\end{array}$ & $\begin{array}{l}5 \text { storey's (parking }+4 \\
\text { storey's) }\end{array}$ \\
\hline Max. density & $65 \%$ & $65 \%$ \\
\hline Building lines & $9.945 \mathrm{~m}$ & $3 \mathrm{~m}$ \\
\hline Side spaces & $3 \mathrm{~m} \& 2.485 \mathrm{~m}$ & $4.78 \mathrm{~m}$ \\
\hline Back boundary & $3 \mathrm{~m}$ & 0 \\
\hline Open spaces & $7 \%$ with a min. of $150 \mathrm{~m}^{\wedge} 2$ & $7 \%$ with a min. of $150 \mathrm{~m}^{\wedge} 3$ \\
\hline $\begin{array}{l}\text { Open areas per dwelling } \\
\text { unit }\end{array}$ & $39 \mathrm{~m}^{\wedge} 2 /$ unit & $39 \mathrm{~m}^{\wedge} 2 /$ unit \\
\hline Parking & 54 & 54 \\
\hline Size of development & $\begin{array}{l}20 \times \text { two bedroom flats } \& 4 x \\
\text { bachelor flats }\end{array}$ & $\begin{array}{l}21 \times \text { two bedroom flats } \& \\
5 \times \text { bachelor flats }\end{array}$ \\
\hline
\end{tabular}

Source: Own construction

No data on origin and destination for the traffic flow exist. From an elementary traffic survey (Table 3) undertaken for the road system serving the property the conclusion can be drawn that the traffic volumes clearly depicts 
movement between places of residence and places of work (including educational facilities). The traffic data profile as contained above confirms the functional classification of adjoining Wilgen Street as a Class $4 \mathrm{~b}$ road in terms of [10] and as shown in Figure 2.

Case 2: Amendment Scheme 1442 provides for the amendment of the Potchefstroom Town Planning Scheme of 1980 from Residential 1 to Residential 4 (linked to Business 2) for dwelling units with or without outbuildings and related business uses. The related business uses will be restricted to ground level only (Refer to Table 2).

As in Case 1 no data on origin and destination for the traffic flow exist.

From the traffic data obtained in the elementary survey (Table 3 and Table 4) the conclusion can be drawn that depicts a strong movement between places of residence and places of work (including educational facilities and hostels of the NWU). The traffic data profile as included above confirms the functional classification of both Hoffman Street and Esselen Street in terms of [10] as Class $4 \mathrm{~b}$ roads.

Table 2 consists of the quantification of the new land use rights applied in Case 1 and Case 2.

\subsection{Intra traffic and modal split}

Case 1: The property is located on Wilgen Street, classified in terms of [10] as a Class $4 \mathrm{~b}$ road (collector linking suburbs). The modal spilt (Table 3 and Table 4) in terms of the survey data consisted of light passenger vehicles; light delivery vehicles (LDV's) minibus-taxis; heavy motor vehicles (HMV's); motorcycles; bicycles and pedestrians. The traffic data is shows for morning and afternoon peak as well as total daily peak demand.

Case 2: The property is located on the north eastern corner of Hoffman and Esselen Street. Both Streets are classified in terms of [10] as Class $4 b$ roads (collector linking suburbs). The modal spilt (Table 3 and Table 4 shows the north/south and south/north movements whilst Table 5 and Table 6 shows the east/west and west/east movement for the modal split.

\section{Existing road capacity, access and parking}

\subsection{Road capacity}

To determine the effect the proposed development will have on the road network, the generated trips are distributed onto the existing road network. It assumes that the percentage of generated trips entering and leaving (exiting) the study area is therefore proportional to the distribution of the existing traffic on the main roads. The approach as contained in the Trip Generation Rates Manual [12] was used to estimate the trips that will be generated by the development. In terms of existing standards [13] a local distributor road (Class 4b) is designed to a capacity of 400 to 1500 peak hour vehicle movements. 
Table 3: $\quad$ Modal split of traffic in (north/south movements).

\begin{tabular}{|c|c|c|c|c|c|c|}
\hline \multirow[t]{2}{*}{$\begin{array}{l}\text { Transport } \\
\text { mode }\end{array}$} & \multicolumn{2}{|c|}{ Morning peak } & \multicolumn{2}{|c|}{ Afternoon peak } & \multicolumn{2}{|c|}{$\begin{array}{c}\text { Total daily peak } \\
\text { demand }\end{array}$} \\
\hline & Case 1 & Case 2 & Case 1 & Case 2 & Case 1 & Case 2 \\
\hline Pedestrians & 47 & 25 & 61 & 42 & 108 & 67 \\
\hline Bicycles & 22 & 24 & 27 & 30 & 49 & 54 \\
\hline Motorcycle & 14 & 12 & 12 & 10 & 26 & 22 \\
\hline $\begin{array}{l}\text { Private } \\
\text { motor } \\
\text { vehicles }\end{array}$ & 88 & 222 & 71 & 234 & 159 & 456 \\
\hline $\begin{array}{l}\text { Minibus- } \\
\text { taxis }\end{array}$ & 5 & 12 & 9 & 15 & 14 & 27 \\
\hline LDV & 8 & 5 & 21 & 6 & 29 & 11 \\
\hline HMV & 3 & 3 & 7 & 2 & 10 & 5 \\
\hline Total & 187 & 309 & 208 & 339 & 395 & 647 \\
\hline
\end{tabular}

Source: [11].

Table 4: $\quad$ Modal split of traffic in (south/north movements).

\begin{tabular}{|c|c|c|c|c|c|c|}
\hline \multirow[t]{2}{*}{$\begin{array}{l}\text { Transport } \\
\text { mode }\end{array}$} & \multicolumn{2}{|c|}{ Morning peak } & \multicolumn{2}{|c|}{ Afternoon peak } & \multicolumn{2}{|c|}{$\begin{array}{c}\text { Total daily peak } \\
\text { demand }\end{array}$} \\
\hline & Case 1 & Case 2 & Case 1 & Case 2 & Case 1 & Case 2 \\
\hline Pedestrians & 39 & 28 & 42 & 23 & 81 & 51 \\
\hline Bicycles & 19 & 31 & 22 & 27 & 41 & 58 \\
\hline Motorcycle & 8 & 16 & 9 & 16 & 17 & 32 \\
\hline $\begin{array}{l}\text { Private } \\
\text { motor } \\
\text { vehicles }\end{array}$ & 88 & 258 & 108 & 213 & 196 & 471 \\
\hline $\begin{array}{l}\text { Minibus- } \\
\text { taxis }\end{array}$ & 6 & 18 & 8 & 20 & 14 & 38 \\
\hline LDV & 12 & 3 & 19 & 12 & 31 & 15 \\
\hline HMV & 13 & 4 & 17 & 5 & 30 & $\overline{9}$ \\
\hline Total & 185 & 358 & 225 & 316 & 410 & 674 \\
\hline
\end{tabular}

Source: [11].

Case 1: From the traffic data as contained above, it is clear that the proposed development may increase traffic movement by $11.27 \%$ for daily peak demand. This is based on an assumption that approximately $40 \mathrm{LMV}$ will be used during peak hours. This factor will not negatively impact on existing road capacity and traffic flow.

Case 2: In the case of Amendment Scheme 1442 it is assumed that approximately 40 new LMV will be added to the existing traffic counts that will 
make use of the road network. If this figure is calculated based on distribution on both North/South and South North movements and East/West and West/East movement it theoretically implies an additional $2.37 \%$ vehicle occupation during the total peak hour demand for both adjacent roads adjoining the development site. Due to the functional classification order of these roads the direction of traffic movement on these roads, to left turn movements only, will have to be considered as to optimise the existing capacity of the road network.

Table 5: $\quad$ Modal split of traffic in Esselen (east/west) (Case 2).

\begin{tabular}{|l|r|r|r|}
\hline Transport mode & Morning peak & Afternoon peak & $\begin{array}{c}\text { Total daily } \\
\text { peak demand }\end{array}$ \\
\hline Pedestrians & 48 & 72 & 120 \\
\hline Bicycles & 15 & 26 & 41 \\
\hline Motorcycle & 12 & 9 & 21 \\
\hline Private motor vehicles & 194 & 178 & 372 \\
\hline Minibus-taxis & 22 & 13 & 35 \\
\hline LDV & 15 & 9 & 24 \\
\hline HMV & 5 & 5 & 10 \\
\hline Total & 311 & 312 & 623 \\
\hline
\end{tabular}

Source: [11].

Table 6: Modal split of traffic in Esselen Street (west/east movements) (Case 2).

\begin{tabular}{|l|r|r|r|}
\hline Transport mode & Morning peak & $\begin{array}{l}\text { Afternoon } \\
\text { peak }\end{array}$ & $\begin{array}{l}\text { Total daily } \\
\text { peak demand }\end{array}$ \\
\hline Pedestrians & 18 & 13 & 31 \\
\hline Bicycles & 31 & 37 & 68 \\
\hline Motorcycle & 5 & 7 & 12 \\
\hline Private motor vehicles & 183 & 203 & 386 \\
\hline Minibus-taxis & 17 & 14 & 31 \\
\hline LDV & 11 & 15 & 26 \\
\hline HMV & 7 & 2 & 9 \\
\hline Total & 272 & 291 & 563 \\
\hline
\end{tabular}

Source: [11].

\subsection{Ingress and egress from the proposed site}

Case 1: In terms of the development proposal access to and from the site will be limited to a single provision. The approval of the amendment scheme will thus not inhibit the movement of traffic on the existing road system. 
Case 2: In terms of the development proposal access to and from the site will be limited to ingress on Hoffman Street (Class 4a road) and egress in Esselen Street (East/West road). This approach will ensure that the additional required capacity towards Hoffman Street will be rerouted through Esselen Street. In order to promote traffic safety the possibility to allow for ingress and egress based on left vehicle movements only should be considered. The approval of the amendment scheme will thus not inhibit the movement of traffic on the existing road system.

\subsection{Parking provision and loading and off loading}

Case 1: Some 54 parking constructed parking bays will be provided on site. No parking will be provided within the road reserve. The area allocated to parking will be sufficient as to accommodate loading and off loading on site. From previous surveys carried out the general motor vehicle ownership within TCC is calculated to be 1.9 motor vehicle units per erf. If the same figure is applied to the proposed development, there will be ample provision for parking on site.

Case 2: In the case of Amendment Scheme 1442 some 45 constructed parking bays will be provided on site. No parking will be provided within the road or any of the adjacent road reserves. The area allocated to parking will be sufficient as to accommodate loading and off loading on the site. From previous surveys carried out the general motor vehicle ownership within TCC is calculated to be 1.9 motor vehicle units per erf. If the same figure is applied to the proposed development, there will be ample provision for parking on site.

\section{$7 \quad$ Traffic safety}

Case 1: The proposed development will not jeopardize traffic safety in the area. From Table 3 and Table 4 it is clear that the road is not generally used by heavy motor vehicles. Ingress and egress from the site will not obscure sight lines and distances.

Case 2: The proposed development will not jeopardize traffic safety in the area subject that the ingress and egress to and from the sites be limited to left turn movements only. From Table 3 to Table 6 it is clear that the road network is used by heavy motor vehicles in limited volumes. Ingress and egress from the sites subject to the recommendations in relation to traffic movement as described above will not obscure sight lines and distances. The average LMV speed in the case of Hoffman Street was measured at $46 \mathrm{~km} / \mathrm{h}$ whilst the figure for Esselen Street is $37 \mathrm{~km} / \mathrm{h}$ on average.

\section{Conclusions}

The following conclusions related to the traffic impact of the proposed developments can be made:

- The road classification as included in the TCC ITP (2008) supports the proposed development. 
- $\quad$ Existing road capacities are adequate as to cater for the additional traffic to be generated by the new developments.

- Sufficient parking, loading and off-loading facilities will be provided on each of the development sites.

- Ingress and egress from the various sites are optimally being provided for, in the various site development plans.

- Measures for improved traffic management will have to be considered.

\section{Recommendations}

The following recommendations should be considered:

- That a detailed transport plan for the study area inclusive of origin and destination traffic surveys be implemented even by small and intermediate towns as to determine the land use and transport relationships.

- Traffic congestion problems experienced in small and intermediate town can often in part be attributed to the lack of accessible alternative modes of transport.

- $\quad$ The simplistic approach illustrated in this paper serves as a benchmark for TIS in small and intermediate towns where limited access to professional capacity exists.

\section{References}

[1] Stover, V.G. and Koepke, F.J. Transportation and Land Development, Institute of Transportation Engineers, Prentice Hall, Englewood Cliffs, New Jersey.

[2] Institute of Transportation Engineers, 1991, Traffic Access and Impact Studies for Site Development, A Recommended Practice, Prepared by the Transportation Planners Council Task Force on Traffic Access/Impact Studies, B.S. Bochner, Chairperson, Washington DC.

[3] Cape Cod Commission Guidelines for Transportation Impact Assessment. Technical Bulletin 96-003. Revised January 9, 2003. www.capecodcommission.org/regulatory/TransTechBulletin2003.pdf

[4] Department of Transport, 1997, Manual for traffic impact studies, BKS (Pty) Ltd, Pretoria

[5] NWU (Potchefstroom Campus) and its Environs Transport Planning Report 2006.

[6] Potchefstroom City Council Bult Densification Report, 2006.

[7] Potchefstroom Land Use Survey, 2004.

[8] Potchefstroom Town Planning Scheme, 1980.

[9] Tlokwe City Council Draft Residential Policy, 2008.

[10] Tlokwe City Council IDP 2007; SDF 2008 and ITP, 2008.

[11] Traffic Research Surveys undertaken in 2006, 2007 and 2008 within the Bult area (Potchefstroom). 
154 Urban Transport XV

[12] South African Trip Generation Rates Manual, Department of Transport, 1995.

[13] Guidelines for the Provision of Engineering Services and Amenities in Residential Townships (1984 and 1994). CSIR, Pretoria. 